\title{
WHO PAYS THE CORPORATE TAX?: INSIGHTS FROM THE LITERATURE AND EVIDENCE FOR CANADIAN PROVINCES ${ }^{\dagger}$
}

\author{
Kenneth J. McKenzie and Ergete Ferede
}

\section{SUMMARY}

Who bears the burden, or incidence, of the corporate income tax (CIT)? This is an important, if not somewhat contentious, policy issue. In this paper we provide a discussion of the existing research on the question, viewing it through a Canadian policy lens. We also use some new results from a companion technical paper, which undertakes one of the few empirical investigations of the issue using Canadian data, to discuss the implications of increases in corporate taxes for wages in Canadian provinces.

While it is clear that people, not corporate entities, ultimately bear the burden of corporate taxes, a key question is which people? The answer to this question has important implications for the equity, or fairness, of the tax system. Much of the recent focus in policy discussions concerns the allocation of the burden of the CIT between owners of capital and labour. Since income from capital tends to be concentrated with wealthier individuals, if the burden of the CIT falls mostly on the owners of capital, it increases the progressivity of the tax system. On the other hand, if the tax is borne mostly by labour through lower wages, the $\mathrm{CIT}$ is less progressive.

Much of the research into the incidence of the CIT has employed theoretical simulation models. Early models of this type, which were based on a closed economy with fixed supplies of labour and capital, suggested that most of the burden of the CIT would be borne by the owners of capital throughout the economy, and not just the shareholders of firms in the corporate sector. Subsequent extensions of those models into a small open economy setting, 
where capital and goods are highly mobile between jurisdictions (countries, provinces), predict that most of the burden of the CIT will be borne by other inputs that are relatively inelastic in supply, such as labour. These small open economy models are particularly relevant for Canada. Viewing the results of these models through a Canadian lens, we conclude that there is good reason to expect that much of the burden of corporate taxes in Canada, particularly those levied by provincial governments, will fall on labour through lower wages.

While useful, the predictions of these simulation models should be viewed with caution, largely because of the sensitivity of the results to the underlying assumptions. A nascent empirical literature has emerged that provides econometric-based estimates of the distribution of the burden of corporate taxes. While this research is relatively new, our reading is that the evidence is mounting that corporate taxes are indeed borne to a significant extent by labour through lower wages. However, there is very little empirical work done in an explicitly Canadian context.

In a companion technical paper we employ Canadian data to examine the impact of provincial corporate taxes on wages. Our results suggest that, consistent with the predictions of the open economy simulation models, provincial corporate taxes adversely affect the capital/labour ratio, which lowers the productivity of labour which, in turn, lowers wages. Accounting for the shrinkage in the corporate tax base in response to an increase in the tax rate, we calculate that for every $\$ 1$ in extra tax revenue generated by an increase in the provincial CIT rate, the associated long-run decrease in aggregate wages ranges from $\$ 1.52$ for Alberta to $\$ 3.85$ for Prince Edward Island. Applying our estimates to the recent 2 percentage point increase in the CIT rate in Alberta we calculate that labour earnings for an average two-earner household will decline by the equivalent of approximately $\$ 830$ per year, which amounts to a $\$ 1.12$ billion reduction in aggregate labour earnings for the province. By way of comparison, other research has estimated the impact of the recently imposed carbon tax in Alberta - the subject of considerable scrutiny - to be approximately $\$ 525$ per household. 


\section{INTRODUCTION}

Who pays the corporate income tax (CIT)? This seemingly simple question does not have a simple answer. Indeed, the question is perhaps one of the more contentious in public finance. The purpose of this paper is two-fold. First, we provide a discussion of the existing research devoted to addressing the question of who pays the CIT, viewing it from a policy perspective through a Canadian lens. Second, we use some new results from a companion technical paper which undertakes one of the few empirical investigations of the issue using Canadian data to discuss the implications of increases in the CIT rate for wages in Canadian provinces.

Some may wonder why there is any question at all regarding who pays the CIT — why corporations do, of course! However, it is important to distinguish between who is legally responsible for paying a tax and who ultimately bears the tax's burden. The study of who bears that burden is referred to as tax incidence analysis. The legal responsibility for paying a tax has little to do with who bears the economic incidence of a tax, as reflected in changes in prices, profits, income, and ultimately, the well-being of individuals. In the case of the CIT, corporations are merely conduits through which income passes to individuals. Thus, people, not corporations, ultimately bear the burden of the CIT. This idea is reflected in the comments of two Nobel Prize-winning economists from opposite sides of the political spectrum. Conservative economist Milton Friedman (1976 Nobel):

How do you "burden" an industry or "tax" a factory? Do you squeeze it until it screams? Send it to jail? Only people can bear a "burden" or pay a tax. An industry, a factory, a utility can do neither. ${ }^{1}$

Liberal economist Wassily Leontief (1973 Nobel):

Corporate income taxes ultimately fall on people. Economists have tried but never succeeded in finding out how the weight of these taxes is ultimately distributed among income groups. ${ }^{2}$

Thus, any tax imposed on a business or corporation will ultimately be passed on to individuals - to consumers through higher prices, to employees through lower wages or to the owners of capital (shareholders) through lower profits.

Why is an understanding of who bears the burden of the CIT important? While it is clear that people, not corporate entities, bear this burden, a key question is which people? The answer to this question has implications for the distribution of the tax across different income groups, owners of different factors of production, etc. This has particular implications for the equity, or fairness, of the tax system. Much of the recent focus in the literature and in policy discussions concerns the allocation of the burden of the CIT between owners of capital and labour. Since income from capital tends to be concentrated with wealthier individuals, if the burden of the CIT falls mostly on capital, it increases the tax system's progressivity. On the other hand, if the tax is borne mostly by labour through lower wages, the CIT is less progressive.

\footnotetext{
As quoted in Gruber (2010), 559.

Leontief (1985).
} 
While we will argue below that some progress has been made in assessing the incidence of the CIT since Leontief's rather dismal assessment, there remains some disagreement regarding how the ultimate burden of the tax is distributed. Particularly relevant for Canada, the prevailing and evolving wisdom is that in a small open economy, where goods and capital are relatively mobile across borders, owners of corporate capital do not bear the entire burden of the CIT. While there is some disagreement on the magnitude, both theoretical simulation exercises and empirical investigations suggest that in a small open economy like Canada labour bears much, and perhaps a great deal, of the burden of the CIT through lower wages.

In a recent paper (McKenzie and Ferede (2017)) we undertake one of the few empirical investigations of the impact of the CIT on wages using Canadian data. We find that a 10 per cent increase in a province's corporate income tax rate is associated with about a 1.0 per cent reduction in the real hourly wage rate. Using the recent increase in the CIT rate in Alberta from 10 per cent to 12 per cent as an example, our estimates suggest this will reduce the income for an average two-earner household in Alberta by about $\$ 830$ per year, an aggregate decrease in labour compensation of $\$ 1.12$ billion (2014 dollars).

Moreover, for 2014, and taking account of the shrinkage in the CIT base in response to changes in the tax rate, our estimates suggest that for every $\$ 1$ increase in corporate tax revenues due to an increase in the provincial statutory CIT rate aggregate wages fall from $\mathrm{C} \$ 1.52$ for Alberta to $\mathrm{C} \$ 3.85$ for Prince Edward Island. These results, which are consistent with the growing empirical research in this area, suggest that a significant part of the corporate income tax liability is borne by workers in the form of lower wages.

In Section II, we provide an overview of the existing literature and its implications for Canada. In Section III, we present some results from our previous empirical analysis and undertake several calculations using those estimates. Section IV concludes.

\section{OVERVIEW OF EXISTING RESEARCH AND ITS IMPLICATIONS FOR CANADA}

Until relatively recently, the research into the incidence of the CIT has been largely theoretical in nature. The typical approach has been to specify a general equilibrium model of the economy, parameterize that model based on estimates of key variables, and simulate the impact of an increase in the CIT on prices, wages, income, well-being, etc. Initially, the bulk of this work took place in a closed economy setting, where there were no flows of goods or capital among jurisdictions. More recently, and of more relevance to Canada, the models have been extended into an open economy setting.

While informative, this theoretical simulation approach has proven to be somewhat unsatisfying, primarily due to fundamental ambiguities and the sensitivity of the results to assumptions regarding the underlying parameters. Recently, there has been an emphasis on empirical research that seeks to determine the distribution of the burden of the CIT. This research has focused largely on assessing the burden borne by labour through reductions in wages.

In what follows, we provide an overview of the research on the incidence of the CIT from two perspectives. First, we review some of the basic theoretical insights. Here we focus on open economy models, as they are the most relevant to the Canadian discussion. 
Next, we provide a brief review of the more recent empirical research. We do not claim to present an exhaustive or in-depth survey of the research on the incidence of the CIT from either perspective, but rather focus on conveying the basic insights relevant to the policy discussion in a Canadian context.

\section{II.1 Theoretical Studies}

The research distinguishes between two channels through which corporate taxes can be passed on to labour: the direct effect and the indirect effect. The fundamental difference between them lies in the assumptions regarding the competitive nature of supply and demand in the relevant markets and the impact of the CIT on marginal incentives in those markets. The indirect effect, which chronologically preceded the development of the direct effect in the literature, essentially assumes perfect competition, most particularly in labour markets where labour is paid the value of its marginal product. In this setting, an increase in the CIT rate depresses the demand for capital, which in turn affects the demand for labour due to an associated reduction in its marginal productivity. Thus, the CIT affects wages indirectly through its impact on capital and hence labour productivity.

More recently, the literature has focused on an alternative channel whereby the CIT affects wages directly. In these models, firms earn economic rents due to imperfect competition and/or other market frictions. Firms and workers bargain over these rents, allowing workers to earn a premium over the value of their marginal product. The CIT lowers the rents available for distribution, which can lead directly to a reduction in wages.

We begin with a discussion of the CIT's indirect effect on wages, then move on to the direct effect. This is followed by a brief discussion of the incidence of the provincial, as opposed to federal, CIT. The section concludes with some comments on small business taxation.

\section{The Indirect Effect}

The work of Arnold Harberger (1962) is often pointed to as the seminal paper in this regard. He developed a two-sector general equilibrium model of the U.S. economy - with a corporate sector subject to a CIT and an untaxed non-corporate sector - and showed that, in principle, the incidence of the CIT could fall on either or both of the owners of capital and labour. Where the bulk of the burden falls is determined by things like the relative factor intensities in the two sectors, the degree of factor substitutability within the sectors, the extent of product substitution, etc. Using plausible estimates of key parameters for the U.S., he concluded that "it is hard to avoid the conclusion that plausible alternative sets of assumptions about the relevant elasticities all yield results in which capital bears very close to 100 per cent of the tax burden" (Harberger 1962, page 234).

Several extensions of Harberger's seminal closed economy model have since been undertaken; some reinforce his conclusion that capital bears the bulk of the burden of the CIT, others question it. For example, Gravelle and Kotlikoff (1993) extend the model to allow for product differentiation and conclude that capital continues to bear the bulk of the CIT's burden under reasonable parameterizations. On the other hand, in their classic public economics book, Atkinson and Stiglitz (1980) introduce several market imperfections into 
the analysis and show that Harberger's result that capital bears the bulk of the tax's burden may no longer hold in some cases.

The insight that, under reasonable conditions, capital bears much of the burden of the CIT hinges critically on the assumption of a closed economy. More relevant for Canada has been the extension of general equilibrium models into an open economy setting, which allows for the flow of goods and capital among jurisdictions. For the remainder of this section, we confine ourselves to a discussion of these open economy models. As will be seen, extending the analysis into an open economy setting generates very different conclusions regarding the potential incidence of corporate taxes.

To begin, it is useful to sketch out a simple model to understand the basic idea behind the indirect channel through which the CIT may be passed on to labour in an open economy. To focus ideas, consider a small open single-sector economy where capital is perfectly mobile internationally, labour is immobile, and output and factor markets are perfectly competitive. The fact that the economy is small and open, and capital is perfectly mobile, means that the prices of both the output good and the net-of-tax return to capital are fixed, determined by international markets; they are therefore unaffected by policy changes in the domestic economy. This essentially closes off any avenue by which a CIT can be transmitted to consumers through higher prices, or to capital owners through lower rates of return, leaving the entire burden of the tax to fall on labour, which is presumed to be immobile across jurisdictions.

In this simple world, an increase in the tax on capital via a rise in the CIT causes capital to move out of the small open economy to lower-taxed jurisdictions. As capital leaves the jurisdiction, and the capital/labour ratio falls, labour becomes less productive, putting downward pressure on wages. Thus, the transmission mechanism is from corporate taxes, to the capital/labour ratio, to wages. This is referred to as the indirect effect because the CIT affects the wage rate indirectly via the capital/labour ratio.

While it highlights the key indirect mechanism by which corporate taxes can be transmitted to wages, this is clearly an extremely simple characterization. Several authors have extended this basic idea to show that the indirect transmission mechanism is more nuanced. Gravelle (2013) provides an in-depth review of open economy general equilibrium incidence models, focusing in particular on four important U.S. studies: Grubert and Mutti (1985), Gravelle and Smetters (2006), Randolph (2006) and Harberger (2008). She argues that the results of these studies cast some doubt on the simple conclusion that labour bears the all (or the bulk) of the burden of the CIT in an open economy setting.

As with all general equilibrium studies, the results hinge on assumptions regarding key parameter values. Gravelle identifies five parameters that play an important role in determining the distribution of the burden of the CIT:

1. The degree of capital mobility. The simple model discussed above assumes that capital is perfectly mobile internationally. This means the net-of-tax rate of return on capital is fixed, and capital can bear none of the burden of the CIT, leaving labour to bear the entire burden of the tax - effectively by assumption. If capital is mobile, but not perfectly so, there is some scope for differences in the net-of-tax rate of return among countries, and domestic capital owners can bear some of the burden of the CIT. Thus, the greater the degree of capital mobility, the greater the share of the CIT borne by labour. 
2. The substitutability between domestic and foreign products. In the simple model discussed above, the domestic good was implicitly assumed to be a perfect substitute for foreign goods. As the degree of substitutability between the domestic and foreign goods decreases, the domestic economy becomes more like a closed economy, and capital owners bear more of the corporate tax burden. Thus, the greater the degree of substitution between domestic and foreign goods, the greater the share of the CIT borne by labour.

3. The size of the country. Above, it was assumed that the country was so small as to have no impact on international goods or factor prices, in particular the return to capital. However, as the size of the country relative to the world capital market increases, so too does its impact on the return to capital. Thus, the smaller the country, the greater the share of the burden of the CIT borne by labour.

4. The degree of substitutability of labour for capital. The less substitutable labour is for capital, the more wages must fall to entice firms to substitute labour for the lost capital as it leaves the jurisdiction in response to the CIT. Thus, the lower the degree of substitutability between labour and capital, the greater will be the share of the burden of the CIT borne by labour.

5. Factor Intensities. As capital leaves the corporate sector in response to the CIT, labour must absorb some of the tax. If the corporate sector is relatively capital-intensive, then the labour-income base is relatively small, resulting in more downward pressure on wages. Thus, the more capital-intensive the corporate sector is, the greater will be the share of the burden of the CIT borne by labour.

The studies Gravelle examined model the open economy in different ways and make different assumptions regarding these parameters; they therefore provide different assessments of the distribution of the burden of the CIT between capital and labour. Gravelle attempts to reconcile the differences across the models and concludes that, using common and reasonable parameter values consistent with the U.S. economy, these open economy studies suggest that for the U.S., approximately 40 per cent of the CIT falls on labour through lower wages and 60 per cent on capital through lower returns. Thus, she concludes, that while moving to an open economy framework means that more of the burden of the CIT falls on labour than in a closed economy setting, capital still bears the majority of the burden.

It is important to emphasize that these studies were conducted in the context of the U.S. economy, and Gravelle's 40/60 split between labour and capital needs to be interpreted in that light. Moreover, as suggested above, the split depends critically on assumptions regarding the underlying parameters, and there is not universal agreement on what those values should be. Unfortunately, we are not aware of any similar studies calibrated to Canadian data. However, we can speculate in general terms about how things might differ in a Canadian context by viewing the results of these open economy models through a Canadian lens.

We think that three key parameters are particularly relevant in this regard - the degree of capital mobility, the size of the country and factor intensities. The international mobility of capital has been the subject of considerable debate in the research. In an important early paper, Feldstein and Horioka (1980) document the high degree of correlation between 
domestic savings and investment in OECD countries. They argue that if capital were perfectly mobile internationally, the correlation between domestic savings and investment would be zero, and they interpret the fact that it is not as evidence that capital is not mobile internationally. Several researchers have questioned the Feldstein-Horioka result, on both econometric and methodological grounds, and for its relevance in light of substantial reductions in capital controls in the ensuing period. ${ }^{3,4}$ More recent studies have concluded that while capital may not be perfectly mobile internationally, it is substantially so, and that mobility has increased over time. ${ }^{5}$ However, the key question in viewing the open economy studies Gravelle considered through a Canadian lens is whether capital mobility in Canada is higher, in some sense, than in the U.S. This is a difficult question, and we are aware of no studies that address it explicitly. Certainly, both inward and outward FDI and trade flows as a percentage of GDP are much higher for Canada than for the U.S., which speaks to the relative importance of trade and capital flows in the two countries. ${ }^{6}$ On balance, our view is that there is no reason to expect that capital mobility in Canada is less than in the U.S., and it may perhaps be more so. Based on point 1 above, this suggests that the share of the burden of the CIT borne by labour in Canada might be greater than the 40 per cent Gravelle determined for the U.S. We will return to the issue of capital mobility below in the context of a discussion of provincial corporate taxes.

With regard to country size, Canada is obviously substantially smaller than the U.S. Therefore, one would expect it to have a much smaller, if any, impact on international factor prices, most particularly the return to capital. On this basis (see point 3 above) this suggests that the share of the CIT borne by labour in Canada would be higher than in the U.S.

With regard to factor intensity, there is some evidence that capital intensity is higher in Canada. For example, a Statistics Canada study (Baldwin et al., 2008), concludes that aggregate capital intensity in Canada is higher than in the U.S. This is primarily due to higher intensity in engineering infrastructure assets. Capital intensity in information and communications technology, on the other hand, is lower in Canada. The higher aggregate capital intensity in Canada is reflective of a different industrial structure, in particular the relatively high importance of the resource sector, which is capital-intensive. As per point 5 above, this higher capital intensity suggests that the share of the CIT burden borne by labour in Canada would be higher than in the U.S.

Thus, while we recognize the difficulties involved, viewing the existing open economy studies through a Canadian lens suggests to us that, on a theoretical basis, there is reason to expect that the share of the CIT borne by labour in Canada would be somewhat higher than suggested by the 40/60 split Gravelle suggests for the U.S.

\footnotetext{
For an early critique, see Frankel (1992).

4 Some argue that the well-documented "home bias" in domestic savings portfolios — investors hold a much larger percentage of their financial portfolios in their home country than one would expect based on the relative size of the domestic market - provides further evidence of the segmentation of capital markets. For example, financial company Vanguard (2014a) reports that while the Canadian market accounts for only four per cent of worldwide equity, Canadians hold 40 per cent of their mutual fund investments in Canadian-domiciled firms. U.S. investors hold 73 per cent of their investments in U.S.-domiciled firms, with the U.S. market accounting for just under 50 per cent of the global equity market (Vanguard 2014b).

5 See for example, Pelgrin and Schich (2008).

6 See World Bank data at http://data.worldbank.org/indicator/BX.KLT.DINV.WD.GD.ZS for FDI and http://data.worldbank. org/indicator/TG.VAL.TOTL.GD.ZS for trade.
} 
While the general equilibrium simulation models discussed above provide important insights into the mechanisms by which the burden of corporate taxes may be distributed between capital and labour, they have their limitations. The models are clearly highly stylized and ignore several important factors that might be valuable in determining the allocation of the tax's burden.

Clausing (2012) identifies several factors not accounted for in these studies. For example, the corporate income tax favours debt-financed investment, as interest payments are deductible for tax purposes while the opportunity cost of equity finance is not. Under some circumstances, e.g., in the presence of highly accelerated depreciation and high inflation, an increase in the CIT rate can actually subsidize debt-financed investment in capital, causing an inflow of capital, which increases the marginal product of labour and therefore the wage rate. Also in this regard, and as pointed out by Auerbach (2005) and Fuest et al., (2015), to the extent that the CIT is a tax on pure profits, or economic rent, it imposes no distortions on capital and would be borne entirely by shareholders.

While the Canadian corporate income tax system is by no means a non-distortionary tax on economic rents, the marginal effective tax rate (METR) on capital has declined significantly over the past decade. For example, Bazel and Mintz (2016) document that the aggregate METR on capital in Canada fell from 38.8 per cent in 2005 to 20.0 per cent in 2015. Thus, while the CIT is far from a non-distortionary tax on economic rents in Canada (in which case the METR would be zero), it has become much less distortionary over time. This suggests that less of the burden of an increase in the statutory CIT rate will be transmitted to labour through the indirect transmission mechanism of lower capital investment.

Another consideration is the extent to which a change in the corporate tax takes place in isolation. For example, if other jurisdictions increase their CIT rates at the same time, there will be no outflow of capital and the key indirect transmission mechanism by which the burden of the CIT is passed on to wages in an open economy will be muted. In this context globally there has been a trend towards lowering CIT rates over the past decade. Canada, however, has been near the front of the pack in this regard, reducing the average federalprovincial CIT rate by almost eight percentage points from 2005 to 2014 , compared to an average 4.4-point reduction for the $\mathrm{G} 7 .^{8}$

\section{The Direct Effect}

As mentioned at the beginning of this section, recent research on the incidence of the CIT has focused on the tax's so-called direct effect. The general equilibrium models discussed above assume that labour markets are competitive, and therefore that workers are paid the value of their marginal product. This emphasizes the indirect transmission mechanism by which the CIT may be passed on to labour, through its impact on the stock of capital and the marginal product of labour. More recently, the literature has focused on an alternative channel whereby the CIT affects wages directly. In these models, firms earn economic rents due to imperfect competition and/or other market frictions. Firms and workers bargain over these rents, allowing workers to earn a premium over the value of their marginal product.

\footnotetext{
This ignores the direct effect of the tax, discussed below.

8 See Chen and Mintz (2015).
} 
This premium can arise because of frictions in the labour market, often associated with union power. If firms earn economic rents and bargain with unions over the distribution of these rents, then an increase in the corporate tax can affect wages directly by lowering the rents available for distribution. Importantly, this can occur even if the corporate tax is a non-distortionary tax on pure economic profits. As one might expect, however, there are some theoretical ambiguities.

For example, Felix and Hines (2009) develop a model whereby firms and unions negotiate over economic rent in a bargaining context. They show that, in principle, the impact on wages of an increase in the CIT rate is ambiguous. On the one hand, an increase in the tax lowers the amount of rent available - the size of the pie to be divided shrinks - which suggests a reduction in the wage premium. On the other hand, the indirect impact of the tax on the competitive wage via the marginal productivity of labour acts to increase rents, which may offset this. If the latter effect is small enough, an increase in corporate taxes will lead to a reduction in the union wage premium, and this effect will be larger the stronger the union's bargaining position.

Riedel (2011) also identifies two opposing effects of an increase in corporate taxes on wages. First, as discussed, an increase in the CIT rate lowers the rent available for distribution. Working against this is the increase in the value of the payroll deduction, which lowers the after-tax cost of labour to firms. She argues that under plausible assumptions the second effect can dominate and an increase in the CIT rate can actually lead to an increase in wages.

Fuest et al., (2015), employ a bargaining model to investigate the direct impact of corporate taxes on wages. They show that the impact depends upon the nature of bargaining. In their model, under individual- or firm-level bargaining, the direct effect of an increase in the CIT rate lowers wages. However, if bargaining takes place on a sector level, the impact is ambiguous. Arulampalam et al., (2012) also employ a model where firms and workers engage in bargaining over rents and show that the impact of an increase in the corporate income tax rate on wages depends upon workers' bargaining power.

\section{Provincial CIT}

The bulk of the theoretical literature on the open-economy incidence of the corporate tax takes place within the context of a unitary tax levied at the national level. The basic approach is to treat the country as a unitary entity, with just one corporate tax, operating in a world economy with (perhaps imperfectly) mobile capital and output. Yet, this is clearly not the case in many countries. Canadian provinces levy their own corporate income taxes, and at relatively high rates. In 2016, the general federal CIT rate was 15 per cent, and the weighted average provincial rate was just under 12 per cent, ranging from a low of 11 per cent in B.C. to a high of 16 per cent in Nova Scotia and Prince Edward Island. ${ }^{9}$ Thus, in a Canadian context, there is not one corporate income tax, but several.

How does this change our view of the mechanisms through which the burden of the CIT may be transmitted to labour? This is particularly relevant to the subsequent discussion

\footnotetext{
See McKenzie (2015). This is a weighted average of the general provincial rates and does not include lower tax rates on manufacturing levied in some provinces.
} 
of our empirical study of the incidence of the CIT in a Canadian provincial context, as we identify our estimates largely off interprovincial variability. Unfortunately, we are not aware of any theoretical studies that explicitly investigate this, but we can offer some insights on the basis of the above discussion.

The first concerns the degree of capital mobility within Canada. Recall the FeldsteinHorioka result suggesting that the international capital markets may be somewhat segmented. Helliwell and McKitrick (1999) undertake a similar investigation using Canadian provincial savings and investment data. They find that the correlation between savings and investment at the provincial level in Canada is effectively zero. An earlier paper by Bayoumi and Klein (1997) and a more recent paper by Gouëdard and Vaillancourt (2011) arrive at a similar conclusion. Notwithstanding difficulties associating these correlations with capital mobility, this implies that while capital may not be perfectly mobile internationally, it appears to be very mobile interprovincially within Canada. All else being equal, this suggests that we might expect the burden of an increase in the CIT rate at the provincial level to fall more on labour than an equivalent increase in the federal CIT rate, as mobile capital moves from the higher-taxed province, lowering labour productivity and wages in that province. Of course, other provinces may benefit from the resulting inflow of capital, causing wages in that province to rise.

Working against this, however, is the fact that labour is also more mobile interprovincially than internationally. Indeed, the open economy general equilibrium models discussed above assume that labour is completely immobile across countries. This is clearly an inappropriate assumption in a national context. To the extent that labour is mobile within a country, workers can move across provincial borders in response to changes in wages. This will put equalizing pressure on wages, perhaps muting the impact of changes in capital, and the CIT, on wages.

How mobile is labour in Canada? Put another way, how integrated are labour markets across Canada? There has been limited research on this question. One study by Emery and Coe (2004) investigates the issue starting from a simple premise based on the law of one price: if Canada's labour markets are highly integrated and therefore labour is highly mobile, real wages across jurisdictions should trend towards being equalized. They use panel unit root tests to investigate the convergence of real wages across Canadian cities over time. Based on data from 1971 to 2000, they conclude that while there is significant convergence in labour real wages, labour markets are not perfectly integrated across Canada. Moreover, and interestingly, they find that Canada had a more integrated national labour market from 1901 to 1950, suggesting that labour mobility may actually have decreased over time.

Another relevant factor is the treatment of multi-province corporations in Canada under the corporate income tax, which gives rise to yet another transmission mechanism by which an increase in provincial CIT rates may be borne by labour. When a corporation operates in more than one province, taxable income earned by that corporation must be allocated across the provinces. This is done in Canada by way of an allocation formula based on the corporation's share of sales and wages in each province. Specifically, the share of corporate taxable income allocated to a province is 50 per cent of the province's share of sales plus 50 per cent of its share of the corporate payroll. 
The implications of the allocation formula for the corporate tax burden at the provincial level are not widely appreciated. Dahlby (2000) examines the issue in the context of Canada's allocation formula. The argument is relatively complex, but the result is that an increase in a province's CIT rate relative to other provinces increases the cost of hiring labour in that province, acting effectively like a payroll tax, even if no capital flows among the provinces. The implication, as per Dahlby (2000, page 405), "is that a significant portion of the provincial corporate income tax burden can fall on labour [even] in the short run", when capital might be considered relatively immobile between provinces.

Our reading of the limited evidence provided by Helliwell and McKitrick (1999), Bayoumi and Klein (1997) and Gouëdard and Vaillancourt (2011) on capital, and Emery and Coe (2004) on labour, is that capital is very mobile across Canadian provinces and labour perhaps less so. Taken together with the insight of Dahlby (2000) regarding the implications of the provincial allocation formula, and viewed through the lens of the theoretical open economy tax incidence models discussed above, this suggests to us that labour will bear a larger share of the burden of provincial corporate income taxes than federal taxes. To be clear, by this we mean an increase in the provincial CIT rate in a particular province, holding the rates in the other provinces constant. If there is a co-ordinated or otherwise across-the-board increase in provincial CIT rates, this will act like an increase in the federal rate, with similar effects.

\section{CCPCs and Small Business Taxation}

The above discussion ignores issues related to small, privately held corporations, or CCPCs (Canadian-controlled private corporations) in the Canadian context. Here, we briefly touch upon a few these issues.

The previous discussion on the mobility of capital implicitly presumed that corporations are large enough to access international capital markets. It is reasonable to suppose that small corporations do not have the same access to international capital markets as large corporations, perhaps due to market failures associated with asymmetric information. As such, capital markets in Canada may be viewed as being segmented along small and large lines. The interjurisdictional mobility of small business capital may thus be viewed as being quite low (certainly internationally, but also interprovincially). Based on the preceding discussion, this suggests that "capital" would be expected to bear a greater share of the burden of the CIT levied on small corporations. We put quotation marks around "capital" to emphasize that it is actually difficult to distinguish between the return to capital and labour in a small business context, as the most important asset in these businesses is typically the entrepreneurial ability (so-called human capital) of the owner(s). This is particularly relevant in the case of professional corporations (doctors, lawyers, dentists and economic consultants).

This is relevant because much of the interest in the incidence of the corporate tax is motivated by distributional considerations. If the share of the CIT borne by "capital" is high for small corporations, as we might expect, and if this "capital income" is earned in large part by high-income earners, then this has clear distributional implications. However, of course, tax incidence cuts both ways - if the bulk of the burden of the CIT lies with owners of small business "capital", then the bulk of the benefit of lower CIT rates imposed on small corporations accrues to those owners as well. Small business tax rates in Canada are 
substantially lower than the general rate imposed on larger corporations: the general federal CIT rate is 15 per cent, and the weighted average provincial rate is about 12 per cent. The federal small business rate is 10.5 per cent, and provincial rates range from zero per cent in Manitoba to eight per cent in Quebec, with most in the range of two to 4.5 per cent. Indeed, the evidence suggests that the vast bulk of the income from small corporations is concentrated with wealthy Canadians. For example, Wolfson et al., (2014) report that more than 70 per cent of the top one per cent of income earners in Canada have ownership in CCPCs.

Moreover, small business owners have significant scope for tax planning, including the deferment of taxes on income held within the corporation, income splitting with family members and capital gains exemptions on qualifying shares. For example, Wolfson and Legree (2015) provide what they call a "conservative" estimate of the revenue costs in Canada from income splitting via CCPCs of approximately half a billion dollars annually.

While there may well be reasons to target some sort of tax relief to small corporations - to address, for example, the informational market failures alluded to above - it is not clear on distributional grounds that a low corporate tax rate on small businesses is the best way to achieve it.

\section{II.2 Empirical Studies ${ }^{10}$}

Our discussion of the theoretical literature examining the incidence of the corporate income tax in the preceding section has identified some of the key mechanisms by which the burden of the CIT may be transmitted to labour through lower wages. An understanding of these mechanisms is important for policy-makers concerned with the distributional impact of corporate taxes. However, despite its important insights, the theoretical literature may be considered somewhat unsatisfying. As those versed in theoretical economic models have no doubt come to expect, the literature is rife with theoretical ambiguities - in principle, almost anything can happen. As is often the case, disagreements over policy come down to disagreements over the value of parameters that we often don't know much about. This dissatisfaction has spawned a nascent empirical literature on the impact of corporate taxes on wages. While this literature is quite small, and more work needs to be done, some trends are emerging.

One of the first empirical studies of the CIT's impact on wages was a working paper by Hassett and Mathur (2006). Employing panel data in OECD countries over 22 years, they estimate that a one per cent increase in the statutory corporate income tax rate leads to an average decrease in wages by about 0.95 per cent across different specifications in the long run. This paper received considerable attention and, not surprisingly, has spawned some criticism. Gravelle and Hungerford (2008), for example, question both the robustness of their results and the plausibility of the magnitude of the estimates. In an updated study, Hassett and Mathur (2015) expand their study to include the incorporation of spatial effects, in particular controlling for tax rates in neighbouring countries. When controlling for spatial effects, they find that the impact of corporate taxes on wages is somewhat lower, but still very high, with a one per cent increase in the statutory tax rate leading to a decrease in wages by about 0.5 per cent.

\footnotetext{
10 This section borrows heavily from McKenzie and Ferede (2017).
} 
Clausing (2013) focuses on identifying the indirect channel by way of the capital/labour ratio. She takes a two-stage approach, first regressing the capital/labour ratio on various CIT measures (and controls), and then wages on the capital/labour ratio (and controls). She uses data on OECD countries from 1981 to 2009. In the first-stage regressions relating the capital/labour ratio to the CIT, she finds no impact — the tax coefficients are statistically indistinguishable from zero. While she does find that the capital/labour ratio is positively correlated with higher wages in the second-stage regression, the lack of association between higher taxes and capital in the first-stage regression causes her to question the indirect transmission mechanism identified in the open economy general equilibrium models.

Desai, Foley and Hines (2007) also investigate the general equilibrium indirect transmission mechanism. They use data on the foreign activities of U.S. multinationals in over 50 countries in a panel data set from 1989 to 2004. Their estimates suggest that labour bears between 45 per cent and 75 per cent of the burden of corporate taxes. Clausing (2013) questions the general equilibrium interpretation given the fact that U.S. multinationals are a small subset of the U.S. corporate sector.

Felix (2007) uses household survey data on wages for 30 countries from 1979 to 2002. This allows her to investigate the impact of corporate taxes on individuals in different skill groups (based on the level of education). She finds that a one percentage point increase in the marginal corporate tax rate reduces wages by 0.7 per cent, and that those reductions are shared relatively equally across skill groups. This is perhaps an implausibly large effect, suggesting that the decrease in wages is more than four times the amount of corporate tax revenue collected, though she argues that it is consistent with the analysis of Harberger (1995) and others.

An emerging literature has focused on the direct transmission mechanism, through rent sharing via wage bargaining. Arulampalam et al., (2012) employ micro firm-level data from nine European countries from 1999 to 2003, exploiting both within-firm and cross-firm variation in corporate taxation to examine the direct effect of corporate taxes on wages. Their preferred estimate of the long-run elasticity of the direct effect on wages with respect to the corporate tax rate is -0.093 . This suggests that a $\$ 1$ increase in corporate taxes would reduce wages by 49 cents.

Other studies have examined corporate tax incidence at the sub-national level. Felix and Hines (2009) investigate the impact of U.S. state-level corporate taxes on the union wage premium, thus focusing on the direct effect. They undertake a cross-sectional analysis using data from 2000, using state-level variation in wages, corporate taxes and the difference between union and non-union wages. Controlling for observable worker characteristics, they find that a one per cent lower state corporate tax rate is associated with a 0.36 per cent higher union wage premium. This suggests that a fully unionized firm captures roughly 54 per cent of the benefits of low tax rates.

Liu and Altshuler (2013) also estimate a model of corporate income tax incidence at the U.S. state level. They allow imperfect competition, which generates economic rents that can be shared between the firm and workers; they thus emphasize the direct channel and control for industry concentration ratios. They use data on individual workers matched with industry- and state-specific marginal effective tax rates and concentration ratios. They estimate a mean elasticity of wages with respect to the industry marginal effective tax rate 
of about -0.03 . This translates into 60 cents in corporate tax liability borne by labour for a $\$ 1$ increase in the corporate tax liability.

Fuest et al., (2015) also focus on the direct effect using sub-national data. They employ firm-level data for German municipalities. Their results suggest that labour bears between 40 per cent to 50 per cent of the burden of corporate taxes. They also investigate the importance of various institutional features. For example, they find that wage responses are more negative for firms under collective bargaining agreements.

Dwenger et al., (2011) also use industry- and region-level data in Germany to identify the direct effect of corporate taxes. They find that corporate taxes reduce wages, though by a relatively small amount: a $€ 1$ increase in corporate taxes lowers hourly wages by from 19 to 29 cents.

Felix (2009) employs individual data at the U.S. state level. She finds that a one percentage point increase in the state marginal corporate tax rate reduces wages from 0.14 to 0.36 per cent. She also finds that the effects are more pronounced for individuals with higher education, and that labour's burden from state taxation has increased over time.

Carroll (2009) also uses data from U.S. states, from 1970 to 2007. He finds that a one per cent increase in the average state and local tax rate lowers real wages by 0.014 per cent. This means that for every $\$ 1$ in state and local corporate tax revenue, wages fall by roughly $\$ 2.50$.

Finally, in one of the few Canadian studies, Ebrahimi and Vaillancourt (2016) use individual-level data from Statistics Canada's Labour Force Survey from 1998 to 2013. They find that corporate taxes have an impact on wages even in the very short term, with a one per cent increase in the CIT rate reducing real wages by between 0.15 and 0.24 per cent.

While the empirical literature on the incidence of the CIT on wages is relatively new, and is faced with data and empirical issues, our reading of the research is that the evidence is mounting that corporate taxes are borne to at least some extent by labour through lower wages. The estimates of the impact vary quite widely, however, and more work is required before we can be confident of the magnitude or share of the burden.

\section{SOME RECENT CANADIAN EVIDENCE}

As indicated above, there is a dearth of both theoretical and empirical research investigating the incidence of corporate taxes in a specifically Canadian setting. In this section, we report on the implications of some recent empirical work we have done using Canadian provincial data (McKenzie and Ferde (2017)). In that paper we focus on identifying the indirect general equilibrium effect of the corporate income tax on wages discussed above, abstracting from the direct effect through rent sharing. As discussed previously, according to the open economy general equilibrium model of corporate tax incidence, corporate income taxes adversely affect capital accumulation, which in turn lowers labour productivity and therefore wages.

We seek to answer two fundamental questions. First, do corporate taxes affect the capital/ labour ratio? Second, does the capital/labour ratio in turn affect the wage rate? Affirmative 
responses to these two questions suggest empirical support for the indirect transmission mechanism highlighted in the general equilibrium models of corporate tax incidence.

To motivate the discussion, consider the scatter plots shown in Figures 1 through 3 . All of the data are at the provincial level for the period 1981-2014, and are measured in logs. In Figure 1 provincial level capital/labour ratios are measured on the vertical axis and the combined federal-provincial statutory CIT rates are on the horizontal axis. It is evident that there is a negative correlation between provincial capital/labour ratios and CIT rates, which is consistent with the notion that higher corporate taxes lower capital formation. Figure 2 plots provincial capital/labour ratios against average hourly wage rates. Here we see a positive relationship - higher (lower) capital/labour ratios are associated with higher (lower) wages. Finally, Figure 3 plots average hourly wages against statutory CIT rates. We see a negative relationship — average hourly wages are negatively correlated with the statutory CIT rate.

\section{FIGURE 1 CAPITAL/LABOUR RATIO VS. COMBINED FEDERAL/PROVINCIAL STATUTORY CIT RATES,} ALL PROVINCES, 1981-2014

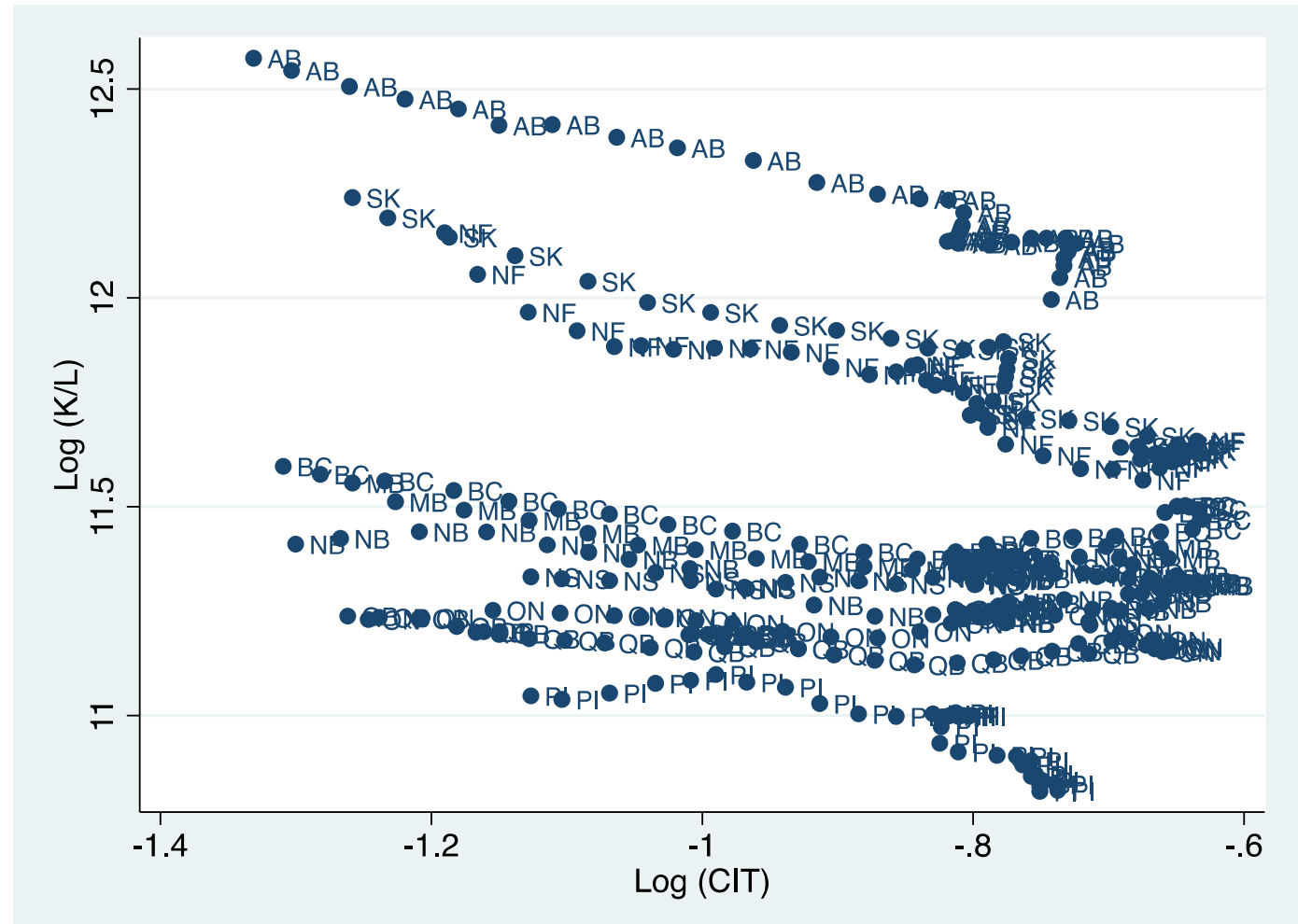

SOURCE: Statutory CIT Rates: Finances of the Nation, Canadian Tax Foundation, various issues. Capital: Aggregate Total Non-Residential Capital Stock (in 2007 dollars), CANSIM 310-007 (capital). Labour: Labour Force Survey, CANSIM 282-0002 
FIGURE 2 AVERAGE HOURLY WAGES VS. CAPITAL/LABOUR RATIO, ALL PROVINCES, 1981-2014

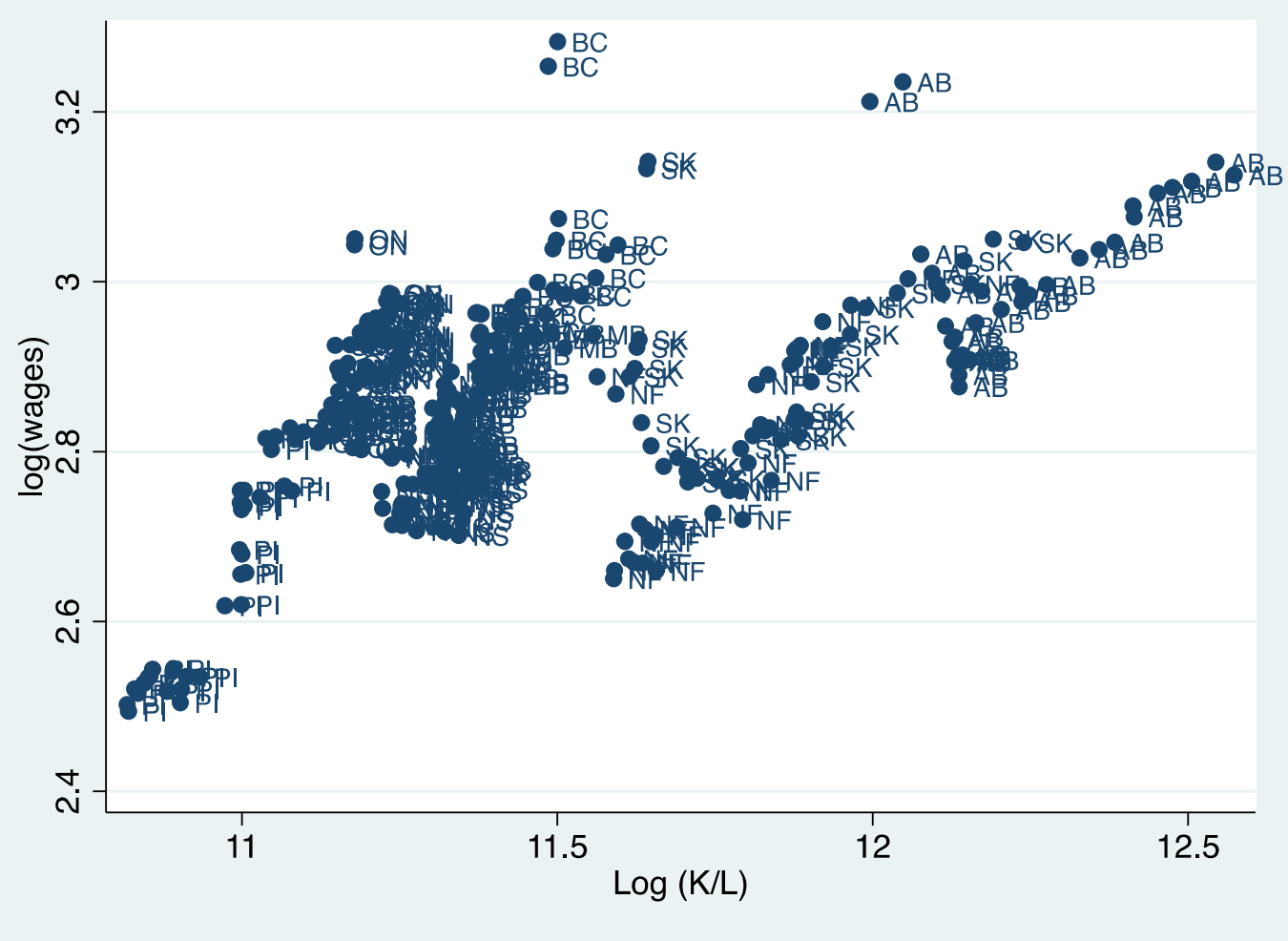

SOURCE: Average Hourly Earnings (all industries) Excluding Overtime: CANSIM 281-0008 and CANSIM 281-0030. Capital/Labour ratio: See Figure 1.

FIGURE 3 AVERAGE HOURLY WAGES VS. STATUTORY COMBINED FEDERAL/PROVINCIAL CIT RATES, ALL PROVINCES, 1981-2014

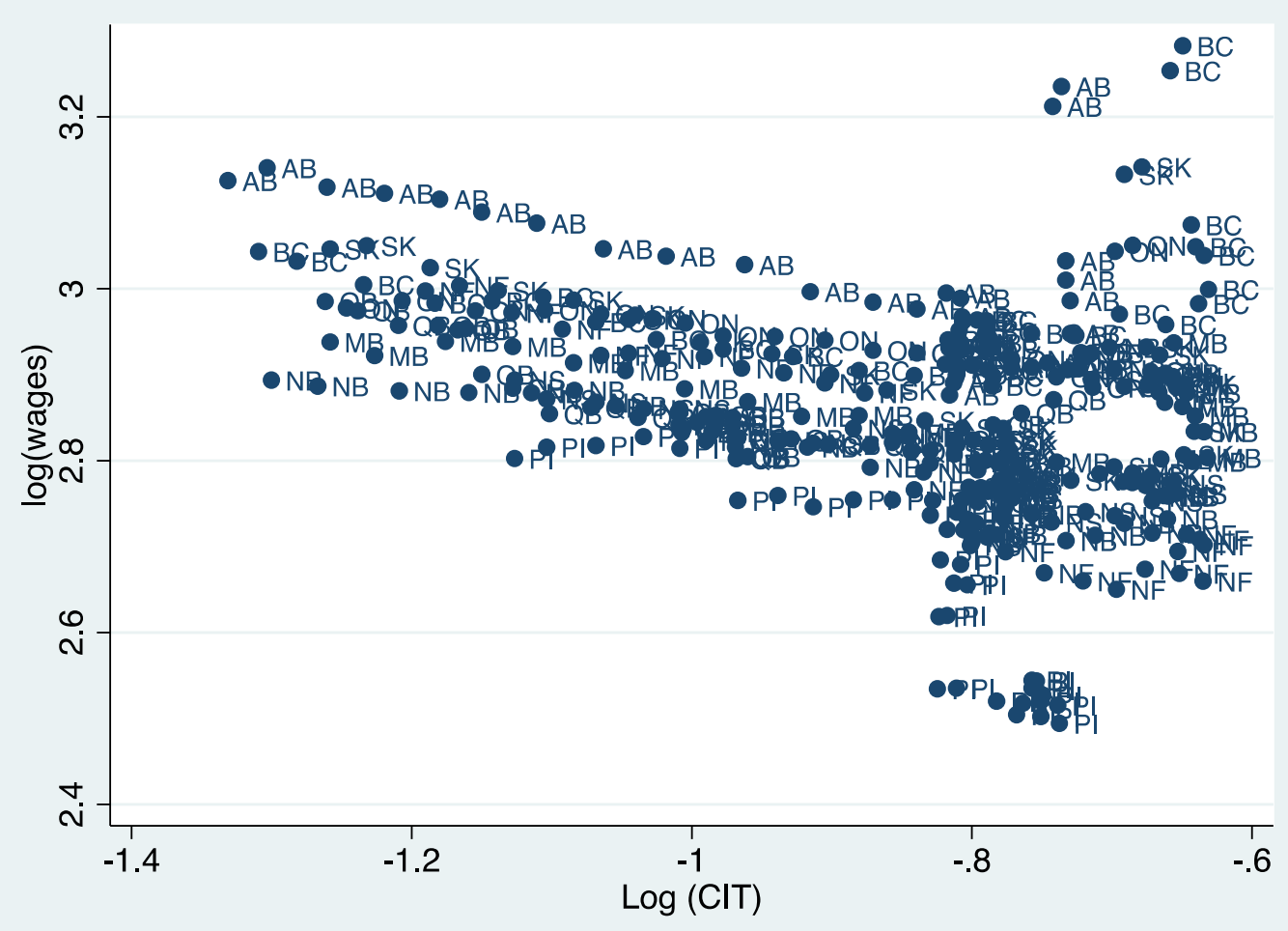


The simple correlations in the raw data shown in Figures 1-3 are consistent with the notion that higher corporate taxes are associated with lower wages by way of the indirect transmission mechanism discussed above. However, it is important to emphasize that the correlations shown in the figures do not imply causation. Capital/labour ratios could differ over time and across provinces for reasons that are independent of differences in corporate tax rates. Similarly, hourly wages may differ for reasons unrelated to the variations in capital/labour ratios and corporate taxes. Proper empirical analysis requires controlling for these other factors in order to isolate and identify the impact of corporate taxes. In McKenzie and Ferede (2017) we undertake a more rigorous empirical analysis. We do not go into details here, but rather sketch the approach and present the key results; readers are referred to that paper for a more detailed discussion.

Our empirical strategy involves the simultaneous estimation of the following two equations:

$$
\begin{aligned}
& \log (K / L)_{i t}=\alpha_{10}+\alpha_{11} \log (C I T)_{i t}+\alpha_{12} X_{i t}+\mu_{i}+\theta_{t}+u_{i t} \\
& \log (\text { Wage })_{i t}=\alpha_{20}+\alpha_{21} \log (K / L)_{i t}+\alpha_{22} Z_{i t}+\mu_{i}+\theta_{t}+\varepsilon_{i t}
\end{aligned}
$$

where $\log (K / L)_{\text {it }}$ is the $\log$ of capital/labour ratio in province $i$ in year $t, \log (C I T)_{\text {it }}$ is the $\log$ of the combined provincial and federal statutory CIT rate, and $\log (\text { Wage })_{\text {it }}$ is the $\log$ of real hourly wage rate. Further, $X_{\text {it }}$ and $Z_{\text {it }}$ denote vectors of relevant control variables which vary both across provinces and over time that are thought to be important in explaining the capital/labour ratio and wage rate, respectively. ${ }^{11}$ This specification allows us to exploit both time series and cross-sectional variation in wages and corporate taxes across provinces. The corresponding error terms in the two equations are denoted by $\varepsilon_{\mathrm{it}}$ and $u_{\mathrm{it}}$.

It is important to note that we also include time-invariant provincial fixed effects, denoted by $\mu_{\mathrm{i}}$, to control for secular differences in wage rates and capital/labour ratios across the provinces. These fixed effects account for unmeasured factors that do not vary over time but are specific to each province which may affect capital/labour ratios and wage rates, such as differences in industrial make-up across the provinces, institutional differences, etc. That such factors may exist is suggested by Figures 1 and 2, where distinct groups of scatter plots suggest the presence of province-specific factors. We also include time effects, $\theta_{t}$, to control for common factors across provinces over time, such as business cycle conditions and other relevant policy changes at the national level.

The coefficients of interest are $\alpha_{11}$ and $\alpha_{21}$ in equations (1) and (2). The coefficient $\alpha_{11}$ is the elasticity of the capital/labour ratio with respect to the statutory CIT rate. It is the percentage change in the capital/labour ratio associated with a one per cent increase in the provincial CIT rate. According to the open-economy model of corporate tax incidence discussed above, we would expect the CIT rate to have a negative impact on the capital/ labour ratio. The coefficient $\alpha_{21}$ is the elasticity of the wage rate with respect to the capital/ labour ratio. It measures the percentage change in the hourly wage rate associated with a one per cent increase in the capital/labour ratio; we would expect this to be positive.

\footnotetext{
11 The control variables $\mathrm{X}$ in the capital/labour regression are the average of CIT rates in other provinces, GDP per capita and a dummy variable for NDP governments. The control variables $\mathrm{Z}$ in the wage regression are personal income tax rates, labour growth rates, unemployment rates, the share of the population with university education, union membership, the openness of the economy and public sector wages.
} 
The elasticity of the wage rate with respect to the CIT rate is then given by the product of these two elasticities, $\alpha_{11}{ }^{*} \alpha_{21}$, which measures the percentage change in the hourly wage rate associated with a one per cent increase in the statutory provincial CIT rate, working through the capital/labour ratio; we expect this to be negative. To account for the possibility that capital/labour ratios and wage rates may take time to adjust to changes in tax rates, all of the data are measured as five-year averages. As such, the elasticity estimates should be interpreted as long-run elasticities.

Table 1 presents the elasticity estimates from our most preferred specification. ${ }^{12} \mathrm{We}$ estimate the elasticity of the capital/labour ratio with respect to the statutory CIT rate to be -0.233 . This means that a 10 per cent increase in the statutory CIT rate at the provincial level will, all else being equal, decrease the capital/labour ratio in that province by 2.33 per cent. The estimated elasticity of the wage rate with respect to the capital/labour ratio is 0.461 ; a 10 per cent decrease in the capital/labour ratio in a province will, all else being equal, decrease the average hourly wage rate by 4.61 per cent. The product of these two elasticities gives an elasticity of the average hourly wage rate with respect to the statutory CIT rate of -0.107 . Thus, our estimates suggest that a 10 per cent increase in a provincial CIT rate will lower the average hourly wage in that province, all else being equal, by 1.07 per cent.

TABLE 1 ESTIMATED K/L AND WAGE RATE ELASTICITIES

\begin{tabular}{|l|c|}
\hline Elasticity of $\mathrm{K} / \mathrm{L}$ with respect to statutory CIT rate & -0.233 \\
\hline Elasticity of average hourly wage rate with respect to K/L & 0.461 \\
\hline Implied elasticity of average hourly wage rate with respect to statutory CIT rate & -0.107 \\
\hline
\end{tabular}

SOURCE: McKenzie and Ferede (2017).

This may seem like a relatively small effect; however, it is actually quite substantial. To see this, we use our estimates to consider the impact of the recent increase in the CIT rate in Alberta. In 2016 the Alberta government increased the provincial CIT rate from 10 per cent to 12 per cent, which increased the combined federal/provincial CIT rate from 25 per cent to 27 per cent, an increase of eight per cent. Our elasticity estimate of -0.107 suggests that this would decrease the real average hourly wage rate in Alberta by 0.86 per cent. In August 2016 the average hourly wage in Alberta was \$29.21. A 0.86 per cent reduction would therefore lower the average hourly wage by a little over 25 cents per hour. ${ }^{13}$ This may not seem like very much, but note that the decrease in the wage rate is permanent and it applies to all wage earners in the province. Assuming an average work week of 32 hours, ${ }^{14}$ this amounts to a reduction in labout income of $\$ 416$ per year for an average individual wage earner; or $\$ 832$ for an average two-earner household. By way of comparison, it might be noted that the impact of the $\$ 30$ carbon tax for an average household in Alberta, is

12 See Ferede and McKenzie (2017) for alternative specifications and robustness checks. Note that in that paper we also use alternative measures of the CIT rate, the marginal effective tax rate and the average tax rate, which yield qualitatively similar results.

13 It is important to note that this reduction is relative to what the wage rate would be in the absence of the increase in the CIT, and that it may not manifest itself in a literal reduction in the observed average wage rate. Wages are continually affected by many forces in the labour market, and will increase or decrease in real terms over time for many reasons. The key point is that whatever those wage rates are, our estimates suggest that they will be lower due to the increase in the CIT rate.

14 This is the average work week in Alberta as given in CANSIM Table 281-0033. 
estimated to be about $\$ 525 .{ }^{15}$ Moreover, consider the decrease in the lifetime earnings of a young Alberta worker who earns the average hourly wage rate for 40 years and works 32 hours per week. Using a discount rate of five per cent, the present value of the decrease in lifetime earnings is about $\$ 7,140$. Therefore, for a young worker, the impact on her wages of a two percentage point increase in the provincial CIT rate is equivalent to taking a little over $\$ 7,000$ away from her today. ${ }^{16}$

As indicated, the estimated reduction in the average hourly wage due to the increase in the CIT rate applies to all wages across the province; the aggregate wage bill is very large. Total labour compensation from wages and salaries in the private sector in Alberta in 2014 was about $\$ 130$ billion; ${ }^{17}$ a 0.86 per cent decrease amounts to a $\$ 1.12$ billion (2014 dollars) decrease in total labour compensation in the province per year.

Another way to appreciate the magnitude of the effect is to consider the impact on aggregate wages of raising one more dollar in corporate tax revenue by way of an increase in the CIT rate. To illustrate this, we use provincial corporate income tax revenue and total wage income in the private sector in 2014. Previous studies, somewhat paradoxically, assume that the corporate tax base remains constant when the tax rate increases to calculate the corporate income tax incidence on wages. In order to compare our results to these studies, we begin by making a similar assumption in our computations, which are shown in column (1) in Table 2.

For instance, for Alberta, total provincial corporate income tax revenue for 2014 was about $\mathrm{C} \$ 5.8$ billion. Thus, a 10 per cent increase in the provincial statutory corporate income tax rate, assuming that the tax base remains constant, leads to an increase in provincial corporate income tax revenue by $\$ 0.58$ billion. In the same year, total wage income in the private sector for the province was about $\$ 130$ billion. Given our elasticity estimate of -0.107 , the 10 per cent increase in the provincial statutory CIT rate — assuming that there is no impact on employment - leads to a decrease of wages in the private sector of about $\$ 0.557$ billion. This means that for every dollar of incremental corporate income tax revenue that the province collects due to an increase in its CIT rate, aggregate wages in the province fall by about 96 cents. Computations for other provinces are done in a similar fashion. Note that since we use the same wage elasticity estimate for all provinces, the variations in the computed corporate income tax incidence on wages across provinces are the result of differences in the provincial statutory CIT rate, total provincial corporate tax revenue collected by the province and total wage payments in the province's private sector.

As indicated above, to make our calculations comparable to previous studies the calculations in column (1) presume that the corporate tax base does not change in response to the increased tax rate. We do not think that this is a reasonable assumption. Dahlby and Ferede (2012) examine the sensitivity of the corporate income tax base to changes in provincial CIT rates. They estimate that, on average, a one percentage point increase in a provincial CIT rate causes the corporate tax base to shrink by 3.67 per cent in the short run, and 13.60 per cent in the long run. This means that an increase in a provincial CIT rate will

15 Winter and Dobson (2016).

16 This also emphasizes the intergenerational impact of the CIT on wages, as the impact is larger the longer one is in the workforce.

17 CANSIM Table 384-0037. 
raise less revenue than presumed in the previous computations, understating the impact of a $\$ 1$ increase in corporate taxes on labour. In column 2 of Table 4, we take the shrinkage in the corporate tax into account, using the semi-elasticity estimates in Dahlby and Ferede (2012). From column (2), we see that the burden of the corporate tax on labour is higher, ranging from $\$ 1.52$ for Alberta to $\$ 3.85$ for Prince Edward Island. Note that the change in the ranking of the provinces occurs due to the fact that the computation is sensitive to the statutory CIT rate. Provinces with a lower CIT rate tend to have lower incidence on wages. It may also be noted that these calculations of the impact of corporate taxes on the wage bill may actually be considered a lower bound as they isolate the indirect effect and ignore any direct effects due to rent sharing.

\section{TABLE 2 CORPORATE INCOME TAX INCIDENCE ON WAGES (IN CANADIAN DOLLARS), 2014}

\begin{tabular}{|l|c|c|}
\hline Province & Constant CIT Base $^{\text {a }}$ & Responsive CIT Base $^{\text {b }}$ \\
\hline British Columbia & 1.34 & 2.25 \\
\hline Alberta & 0.96 & 2.52 \\
\hline Saskatchewan & 1.12 & 2.01 \\
\hline Manitoba & 1.52 & 2.72 \\
\hline Ontario & 1.14 & 1.97 \\
\hline Quebec & 0.98 & 1.74 \\
\hline New Brunswick & 1.74 & 3.12 \\
\hline Nova Scotia & 1.18 & 2.86 \\
\hline Prince Edward Island & 1.59 & 3.85 \\
\hline Newfoundland and Labrador & 0.95 & 1.95 \\
\hline
\end{tabular}

SOURCE: McKenzie and Ferede (2017). Authors' computations based on the estimated wage elasticity with respect to the corporate income tax rate (see Table 1) and provincial corporate income tax revenue and wage income data for 2014. The figures show the dollar amount by which wages decrease due to a $\$ 1$ increase in corporate income tax liability.

assumes the CIT base remains constant in response to an increase in the tax rate.

${ }^{b}$ Assumes the CIT base shrinks in response to an increase in the tax rate. Uses semi-elasticity estimates from Dahlby and Ferede (2012) to calculate the shrinkage in the tax base.

\section{CONCLUDING COMMENTS}

Corporate income tax incidence - who bears the burden of the corporate income tax - is one of the more contentious issues in tax policy discussions. Since corporations are merely conduits through which income passes to individuals, it is not clear who ultimately bears the burden of corporate taxes. The issue has important implications for the overall fairness of the tax system and the determination of the distribution of tax burdens across different factor owners and income groups. Consequently, in this paper we endeavour to achieve two main objectives. First, we draw on insights from the existing theoretical literature about the effects of corporate income tax on wages, viewing this literature through a Canadian lens. Second, we report on the implications of some recent empirical work we have done which estimates the effect of corporate income taxes on wages in Canadian provinces.

The theoretical literature on corporate tax incidence suggests that the corporate income tax can adversely affect wages through two main channels. According to the general equilibrium open-economy model of corporate income tax incidence, an increase in the CIT rate raises the user cost of capital and depresses the demand for capital. This is 
particularly important in a small open economy like Canada where capital is mobile, the country is very small relative to international financial markets, and therefore the net-oftax return to capital is fixed by international markets. This in turn affects the demand for labour due to an associated reduction in its marginal productivity. The decrease in labour productivity ultimately reduces wages. This is commonly referred to in the literature as the indirect effect since the CIT affects wages indirectly through its impact on capital and hence labour productivity. More recently, the literature has focused on an alternative channel whereby the CIT affects wages directly - the so-called direct effect. In these models, firms earn economic rents, due to imperfect competition and/or other market frictions. Firms and workers bargain over these rents, allowing workers to earn a premium over the value of their marginal product. The CIT lowers the rents available for distribution, which can lead directly to a reduction in wages.

The theoretical literature therefore suggests that, particularly for a small open economy like Canada, there is strong reason to expect that a substantial share of the burden of corporate income taxes will fall on labour, via both the indirect and the direct effects.

Despite the importance of corporate income tax incidence for policy-makers, the empirical literature on this issue is relatively new and limited. The studies vary widely in their data coverage and empirical approaches. Some of the studies are also plagued with various data and empirical issues. Nonetheless, our reading of the current research is that the evidence is mounting that corporate taxes are borne to a significant extent by labour through lower wages. The estimates of the impact vary quite widely, however, and more work is required before we can be confident of the share of the burden borne by workers.

In McKenzie and Ferede (2017) we conduct one of the few empirical investigations of the issue using Canadian data, specifically panel data of Canadian provinces from 1981 to 2014. Our empirical results indicate that the CIT rate adversely affects the capital/labour ratio, which in turn reduces wages. Taking account of the shrinkage in the corporate income tax base in response to an increase in the tax rate, our computations suggest that for every $\$ 1$ increase in corporate tax revenue due to an increase in the provincial CIT rate, the associated decrease in aggregate wages ranges from $\mathrm{C} \$ 1.52$ for Alberta to $\mathrm{C} \$ 3.85$ for Prince Edward Island. Thus, our empirical results suggest that the CIT has a significant negative indirect effect on wages in Canada, operating through the capital/labour ratio.

Increases in corporate income taxes have, at times, been a popular policy choice for governments seeking revenue. One possible explanation for this is that they may be viewed as being progressive due to the perception that the burden of the tax falls largely on corporate profits, and therefore on the owners of corporate capital. Insights from the existing literature and our empirical analysis based on Canadian provincial data suggest that this perception may be misplaced, and that a significant part of the burden of corporate taxes falls on workers in the form of a wage reduction. This means that corporate income taxes are a less progressive way of raising government revenue than is typically presumed in the public discourse.

A complementary perspective is that the economic costs associated with increases in corporate taxes are borne through wage reductions by a large and diffuse number of individuals over a long period of time. Moreover, the indirect transmission mechanism which is the focus of this paper suggests that the connection between corporate taxes and 
wages, though real and significant, is perhaps somewhat opaque. While in aggregate and over the long run these costs are quite substantial, governments doing the political calculus of weighing the diffuse and opaque long-term costs against the more visible perceived short-term political benefits of raising corporate taxes may opt to impose the former in pursuit of the latter. 


\section{REFERENCES}

Arulampalam, Wiji, Michael P. Devereux, and Giorgia Maffini. 2012. "The Direct Incidence of the Corporate Income Tax on Wages.” European Economic Review 56: 1038-1054.

Atkinson, Anthony, and Joseph Stiglitz. 1980. Lectures on Public Economics. New York: McGraw-Hill.

Auerbach, Alan J. 2005. "Who Bears the Corporate Tax? A Review of What We Know." NBER Working Paper no. 11686.

Baldwin, John R., Anthony Fisher, Wulong Gu, Frank Lee, and Benoit Robidoux. 2008. "Capital Intensity in Canada and the United States, 1987 to 2003." The Canadian Productivity Review, Statistics Canada Catalogue no. 15-206-X -no. 018.

Bayoumi, Tamim, and Michael W. Klein. 1997. "A Provincial View of Capital Mobility." International Monetary Fund Staff Papers 44(4): 534-556.

Bazel, Phil, and Jack M. Mintz. 2016. “2015 Tax Competitiveness Report: Canada is Losing Its Attractiveness.” SPP Research Paper vol. 9(47). The School of Public Policy, University of Calgary.

Carroll, Robert. 2009. "Corporate Tax and Wages: Evidence from the 50 States." Tax Foundation Working Paper no. 8.

Chen, Duanjie, and Jack Mintz. 2006. "Federal/Provincial Combined Marginal Effective Tax Rates on Capital 1997-2006." Supplementary information for Business Tax Reform: More Progress Needed. C.D. Howe Institute e-brief.

Chen, Duanjie, and Jack M. Mintz. 2012. "2012 Annual Global Tax Competitiveness Ranking - a Canadian Good News Story.” SPP Research Paper, vol. 5(28). The School of Public Policy, University of Calgary.

Chen, Duanjie, and Jack M. Mintz. 2015. “The 2014 Global Tax Competitiveness Report: A Proposed Business Tax Reform Agenda.” SPP Research Paper 8(4). The School of Public Policy, University of Calgary.

Clausing, Kimberly A. 2012. "In Search of Corporate Tax Incidence." Tax Law Review 65: 433-472.

Clausing, Kimberly A. 2013. "Who Pays the Corporate Tax in a Global Economy?" National Tax Journal 66(1): 151-184.

Dahlby, Bev. 2000. "Tax Coordination and Tax Externalities," in "Recent Developments in Tax Coordination: A Panel Discussion by Bev Dahlby, Robert Henry, Michael Keen, and David E. Wildasin.” Canadian Tax Journal 48(2): 399-409.

Dahlby, Bev and Ergete Ferede. 2012. "The Effects of Tax Rate Changes on Tax Bases and the Marginal Cost of Public Funds for Canadian Provincial Governments." International Tax and Public Finance 19: 844-883.

Desai, M., Fritz Foley, and James Hines.2007. "Labor and Capital Shares of the Corporate Tax Burden: International Evidence.” Available at http://www.people.hbs.edu/mdesai/publications. 
Dwenger, Nadja, Pia Rattenhuber, and Viktor Steiner. 2011. "Sharing the Burden: Empirical Evidence on Corporate Tax Incidence." School of Business \& Economics Discussion Paper: Economics, no. 2011/19.

Ebrahimi, P., and F. Vaillancourt. 2016. "The Effect of Corporate Income and Payroll Taxes on the Wages of Canadian Workers." Vancouver: Fraser Institute.

Feldstein, Martin, and Charles Horioka. 1980. "Domestic Savings and International Capital Flows." Economic Journal 90: 314-329.

Felix, R. Alison. 2007. "Passing the Burden: Corporate Tax Incidence in Open Economies." Federal Reserve Bank of Kansas City Working Paper.

Felix, R. Alison. 2009. “Do State Corporate Income Taxes Reduce Wages?” Federal Reserve Bank of Kansas City Working Paper.

Felix, R. Alison, and James R. Hines. 2009. "Corporate Taxes and Union Wages in the United States.” NBER Working Paper no. 15263.

Frankel, Jeffrey A. 1992. "Measuring International Capital Mobility: A Review." American Economic Review 82(2): 197-202.

Fuest, Clemens, Andreas Peichl, and Sebastian Siegloch. 2015. "Do Higher Corporate Taxes Reduce Wages?" IZA Discussion Paper no. 9606. Bonn, Germany: The Institute for the Study of Labour.

Gouëdard, P., and F. Vaillancourt. 2011. “Taux d'investissement privé et épargne des ménages des provinces candiennes, 1990-2008; y-a-t-il une relation?" Project Report 2011RP-14, Cirano.

Gravelle, Jane G., and Thomas Hungerford. 2008. "Corporate Tax Reform: Should We Really Believe the Research?” Tax Notes no. 419: 429.

Gravelle, Jane G., and Laurence J. Kotlikoff. 1993. "Corporate Tax Incidence and Inefficiency when Corporate and Non-corporate Goods are Close Substitutes." Economic Inquiry 31(4): 501-516.

Gravelle, Jane G., and Kent A. Smetters. 2006. "Does the Open Economy Assumption Really Mean that Labor Bears the Burden of a Capital Income Tax?" The B.E. Journal of Economic Analysis \& Policy, Advances in Economic Analysis and Policy 6(1), article 3.

Gravelle, Jennifer. 2013. "Corporate Tax Incidence: Review of General Equilibrium Estimates and Analysis.” National Tax Journal 66(1): 184-214.

Gruber, Jonathan. 2010. Public Finance and Public Policy, $3^{\text {rd }}$ ed. New York: Worth Publishers.

Grubert, Harry, and John Mutti.1985. "The Taxation of Capital Income in an Open Economy: The Importance of Resident-Nonresident Tax Treatment." Journal of Public Economics 27(3): 291-309.

Harberger, Arnold C. 1962. "The Incidence of the Corporation Income Tax." Journal of Political Economy 70(3): 215-240. 
Harberger, Arnold C. 1995. "The ABCs of Corporation Tax Incidence: Insights into the Open-Economy Case," in Tax Policy and Economic Growth. Washington, D.C.: American Council for Capital Formation.

Harberger, Arnold C. 2008. "Corporate Tax Incidence: Reflections on what is Known, Unknown and Unknowable," edited by John W. Diamond and George R. Zodrow, in Fundamental Tax Reform: Issues, Choices, and Implications. Cambridge, MA: MIT Press, 283-308.

Hassett, Kevin A., and Aparna Mathur. 2006. "Taxes and Wages.” American Enterprise Institute Working Paper no. 128, June.

Hassett, Kevin A., and Aparna Mathur. 2015. "A Spatial Model of Corporate Tax Incidence." Applied Economics 47(13): 1350-1365.

Helliwell, John F., and Ross McKitrick. 1999. “Comparing Capital Mobility Across Provincial and National Borders." Canadian Journal of Economics 32(5): 1164-1173.

Leontief, Wassily W. 1985. "What It Takes to Preserve Social Equity Amid Dynamic Free Enterprise.” New York Times, Feb. 1, 1985.

Liu, Li, and Rosanne Altshuler. 2013. "Measuring the Burden of the Corporate Income Tax under Imperfect Competition.” National Tax Journal 66(1): 215-238.

McKenzie, Kenneth J. 2015. "The Corporate Income Tax in Canada: Past, Present and Future.” Canadian Tax Journal 63(4): 1011-1026.

McKenzie, Kenneth J., and Ergete Ferede. 2017. "The Incidence of the Corporate Income Tax on Wages: Evidence from Canadian Provinces," SPP Technical Paper, The School of Public Policy, the University of Calgary.

Parsons, M. 2008. "The Effect of Corporate Taxes on Canadian Investment: An Empirical Investigation.” Working Paper 2008-01. Ottawa: Department of Finance.

Pelgrin, Florian, and Sebastian Pelgrin. 2008. "International Capital Mobility: What do National Saving-Investment Dynamics Tell Us?” Journal of International Money and Finance 27: 332-344.

Randolph, William C. 2006. "International Burdens of the Corporate Income Tax." CBO Working Paper no. 2006-09. Washington, D.C.: Congressional Budget Office.

Riedel, Nadine. 2011. "Taxing Multinationals under Union Wage Bargaining.” International Tax and Public Finance 18(4): 399-421.

Vanguard. 2014a. "Global Equities: Balancing Home Bias and Diversification - A Canadian Investor's Perspective.” Vanguard Research, July 2014. Available at https://www. vanguardcanada.ca/documents/global-equities-tlor.pdf)

Vanguard. 2014b. "Global Equities: Balancing Home Bias and Diversification." Vanguard Research, February 2014. Available at https://www.vanguard.com/pdf/ISGGEB.pdf)

Winter, Jennifer and Sarah Dobson. 2016. "Who is Getting a Carbon Tax Rebate?" SPP Communique Vol. 8, Issue 10, The School of Public Policy, University of Calgary. 
Wolfson, Michael, Neil Brooks, and Mike Veall. 2014. "Piercing the Veil: Private Corporations and the Income of the Affluent." Mimeo. Available at https://uwaterloo.ca/ school-of-accounting-and-finance/sites/ca./school-of-accounting-and-finance/files/uploads/ files/wolfson-brooks-veall-_incomes_of_affluent.pdf

Wolfson, Michael, and Scott Legree. 2015. "Policy Forum: Private Companies, Professionals, and Income Splitting — Recent Canadian Experience." Canadian Tax Journal 63(3): 717-737. 


\title{
ABOUT THE SCHOOL OF PUBLIC POLICY
}

The School of Public Policy has become the flagship school of its kind in Canada by providing a practical, global and focused perspective on public policy analysis and practice in areas of energy and environmental policy, international policy and economic and social policy that is unique in Canada.

The mission of The School of Public Policy is to strengthen Canada's public service, institutions and economic performance for the betterment of our families, communities and country. We do this by:

- Building capacity in Government through the formal training of public servants in degree and non-degree programs, giving the people charged with making public policy work for Canada the hands-on expertise to represent our vital interests both here and abroad;

- Improving Public Policy Discourse outside Government through executive and strategic assessment programs, building a stronger understanding of what makes public policy work for those outside of the public sector and helps everyday Canadians make informed decisions on the politics that will shape their futures;

- Providing a Global Perspective on Public Policy Research through international collaborations, education, and community outreach programs, bringing global best practices to bear on Canadian public policy, resulting in decisions that benefit all people for the long term, not a few people for the short term.

Our research is conducted to the highest standards of scholarship and objectivity. The decision to pursue research is made by a Research Committee chaired by the Research Director and made up of Area and Program Directors. All research is subject to blind peer-review and the final decision whether or not to publish is made by an independent Director.

\author{
The School of Public Policy \\ University of Calgary, Downtown Campus \\ 906 8th Avenue S.W., 5th Floor \\ Calgary, Alberta T2P $1 \mathrm{H} 9$ \\ Phone: 4032103802
}

\section{DISTRIBUTION}

Our publications are available online at www.policyschool.ca.

\section{DISCLAIMER}

The opinions expressed in these publications are the authors' alone and therefore do not necessarily reflect the opinions of the supporters, staff, or boards of The School of Public Policy.

\section{COPYRIGHT}

Copyright (C) 2017 by The School of Public Policy.

All rights reserved. No part of this publication may be reproduced in any manner whatsoever without written permission except in the case of brief passages quoted in critical articles and reviews.

\section{DATE OF ISSUE \\ April 2017}

\section{MEDIA INQUIRIES AND INFORMATION}

For media inquiries, please contact Morten Paulsen at 403-220-2540. Our web site, www.policyschool.ca, contains more information about The School's events, publications, and staff.

\section{DEVELOPMENT}

For information about contributing to The School of Public Policy, please contact Paul Beaudry by telephone at 403-220-4624 or by e-mail at paul.beaudry1@ucalgary.ca.

\section{ISSN}

1919-112x SPP Research Papers (Print)

1919-1138 SPP Research Papers (Online) 


\section{RECENT PUBLICATIONS BY THE SCHOOL OF PUBLIC POLICY}

NATIONAL PHARMACARE IN CANADA: 2019 OR BUST?

http://www.policyschool.ca/wp-content/uploads/2017/03/National-Pharmacare-Adams-Smith.pdf Owen Adams and Jordyn Smith | March 2017

\section{POLICY RESPONSIVENESS AND POLITICAL ACCOUNTABILITY IN CITY POLITICS}

http://www.policyschool.ca/wp-content/uploads/2017/03/Policy-Responsiveness-Sayers-Lucas.pdf Anthony Sayers and Jack Lucas | March 2017

\section{0,000 INACTIVE OIL WELLS: A BLESSING OR A CURSE?}

http://www.policyschool.ca/wp-content/uploads/2017/02/Inactive-Oil-Wells-Muehlenbachs-1.pdf Lucija Muehlenbachs | February 2017

DISCERNING 'FUNCTIONAL AND ABSOLUTE ZERO': DEFINING AND MEASURING AN END TO HOMELESSNESS IN CANADA

http://www.policyschool.ca/wp-content/uploads/2017/01/Absolute-Zero-Turner-Albanese-Pakeman.pdf

Alina Turner, Tom Albanese and Kyle Pakeman | January 2017

\section{PUBLIC-INTEREST BENEFIT EVALUATION OF PARTIAL-UPGRADING TECHNOLOGY}

http://www.policyschool.ca/wp-content/uploads/2017/01/PIB-Evaluation-Fellows-Mansell-Schlenker-Winter.pdf G. Kent Fellows, Robert Mansell, Ronald Schlenker and Jennifer Winter | January 2017

MUNICIPAL REVENUE GENERATION AND SPRAWL: IMPLICATIONS FOR THE CALGARY AND EDMONTON METROPOLITAN REGIONS DERIVED FROM AN EXTENSION OF "CAUSES OF SPRAWL" (TECHNICAL PAPER)

http://www.policyschool.ca/wp-content/uploads/2016/12/MRG-Technical-Paper-McMillan.pdf Melville McMillan | December 2016

MUNICIPAL REVENUE GENERATION AND DEVELOPMENT IN THE CALGARY AND EDMONTON METROPOLITAN REGIONS

http://www.policyschool.ca/wp-content/uploads/2016/12/MRG-Development-Conger-Dahlby-McMillan.pdf Brian Conger, Bev Dahlby and Melville McMillan | December 2016

THE CORPORATE INCOME TAX IN CANADA: DOES ITS PAST FORETELL ITS FUTURE? 2015 TAX-COMPETITIVENESS REPORT: CANADA IS LOSING ITS ATTRACTIVENESS

http://www.policyschool.ca/wp-content/uploads/2016/12/Corporate-Income-Tax-Bird-Wilson.pdf Richard Bird and Thomas Wilson | December 2016

http://www.policyschool.ca/wp-content/uploads/2016/11/Tax-Competitiveness-Bazel-Mintz.pdf Philip Bazel and Jack Mintz | November 2016

\section{IF IT MATTERS, MEASURE IT: UNPACKING DIVERSIFICATION IN CANADA}

http://www.policyschool.ca/wp-content/uploads/2016/11/Diversification-in-Canada-Tombe-Mansell.pdf Trevor Tombe and Robert Mansell | November 2016

\section{ALBERTA'S NEW ROYALTY REGIME IS A STEP TOWARDS COMPETITIVENESS: A 2016 UPDATE}

http://www.policyschool.ca/wp-content/uploads/2016/10/AB-New-Royalty-Regime-Crisan-Mintz-final.pdf Daria Crisan and Jack Mintz | October 2016

A RULE OF REASON FOR INWARD FDI: INTEGRATING CANADIAN FOREIGN INVESTMENT REVIEW AND COMPETITION POLICY http://www.policyschool.ca/wp-content/uploads/2016/10/Foreign-Investment-Bishop-Final.pdf Grant Bishop | October 2016 